University of Michigan Law School

University of Michigan Law School Scholarship Repository

1920

\title{
Recovery of Life Insurance When Insured Died in Military Service
}

\author{
Ralph W. Aigler \\ University of Michigan Law School
}

Available at: https://repository.law.umich.edu/articles/1253

Follow this and additional works at: https://repository.law.umich.edu/articles

Part of the Courts Commons, and the Insurance Law Commons

\section{Recommended Citation}

Aigler, Ralph W. "Recovery of Life Insurance When Insured Died in Military Service." Mich. L. Rev. 18 (1920): 686-9.

This Response or Comment is brought to you for free and open access by the Faculty Scholarship at University of Michigan Law School Scholarship Repository. It has been accepted for inclusion in Articles by an authorized administrator of University of Michigan Law School Scholarship Repository. For more information, please contact mlaw.repository@umich.edu. 
Recovery of Life, Insurance, When Insured Died in Military Service -A group of very recent cases, representative no doubt of many others pending, involve an interesting and important question as to the construction of military and naval service clauses in life insurance policies. These clauses which have been common in policies, at least in those issued in the last few years, while varying in wording-and these variations may be vitally important,-provide in general that if the insured meets death while engaged in military or naval service the liability of the insurer shall be limited to the premiums paid, unless permission to engage in such service shall have been obtained from the company and an extra payment made.

The question which has troubled the courts has been whether recovery of the full amount of the insurance should be denied if it appears merely . that the insured died while in service, or if the company escapes such liability only when it appears that service caused death. In other words, does the provision in question raise simply a question of status? or does it involve the more troublesome problem of causation? The large number of deaths at the camps and even abroad from the influenza epidemic and other common diseases to which civilians were by no means immune has already resulted in a number of reported decisions.

At the outset there may be placed on one side those policies where the wording expressly requires for exemption from full liability a causal relation between the service and death. Such a case was Kelly v. Fid: Mut. Life Ins. Co., (Wis.) 172 N. W. 152 (1919), where the insured was killed while riding a motorcycle in the performance of his duties as supervisor of construction and operation of sawmills, I00 miles back of the front in France. The policy contained provision that "If insured shall $* * *$ engage in any military or naval service $* * *$ and shall die within two years of the date of this policy as a result, directly or indirectly, of engaging in such service or work," the liability of the company should be limited to return of premiums paid. The court concluded that the military service was not the cause of death, the deceased not having been exposed to any more hazard than any other motorcycle rider, and that the company was therefore not liable for the full sum. So also Malone v. State Life Ins. Co., (Mo. App.) 213 S. W. 877 (1919), where the insured died while at Jefferson Barracks "of accidental gunshot wound in abdomen, in line of duty." The court held there was no proof that death was the "result of such service." The only question about these cases is whether there was not really a causal connection between service and death. It is probably safe to say that if the insured in both these cases had been killed while doing what they were in the course of an employment and questions had arisen whether the injuries had arisen "out of" such employment so as to be covered by the usual Workmen's Compensation Act, it would have been held that there was sufficient causal relation. See 16 Micf. L. REv. I79; I7 MicH. L. REv: 280 . Of course in these compensation cases the natural tendency is to make the Act inclusive, while in the insurance cases there surely is no disposition normally to let out the company, the rule of construction is properly against it. The above cases, however, hardly tumed on construction. 
The tendency to construe insurance contracts strictly against the insurer is well shown by Redd v. American Central Life Ins. Co.. 200 Mo. App. 383 (1918). The application there read "That active service in the army or navy, in time of war, shall invalidate said contract of insurance, unless a permit," etc.; and the policy provided: "In case of death from service in war without permission from the company, the full reserve for this policy at the time of such death only will be paid." The court (Ellison P. J.. dissenting) concluded that the insured, who had died of pneumonia while stationed at Fort Riley, was not in "active service."

In Miller v. Ill. Bankers Life Ass'n. (Ark.) 212 S. W. 310 (I010), the policy provided that recovery was to be limited to amounts actually paid to company if death occurred "while in the service of the Army or Navy of the government in time of war." In an opinion by McCullough. C. J.. the court held that these words referred to the period of time during which the insured was in service in the army and therefore since the insured died of pneimonia while at camp after induction into the army recovery should be limited to the premiums paid. This case was distinguished in Benham v. American Central Life Ins. Co., (Ark) 217 S. W. 462 (Ig20), where the provision'in the policy limited recovery to the reserve thereon if death ocelirred "vihile engaged in military or naval service in time of war, or in conseguence of such service." Stress was placed on the word "engaged." The court (Smith, J., dissenting, and McCullough, C. J., not participating) said "word 'engased' denotes action. *** So here the words 'death while engaged in military service in time of war' mean death while doing, performing, or taking past in some military service in time of war; in other words, it must be death caused by performing some duty in the military service." The insured having contracted influenza while en route from Cornell University, where he had been sent for special training, to Camp Dick to await assignment, from which he died, the court concluded the full amount of the policy was recoverable. Again in Nutt v. Security Life Ins. Co. of America, (Ark.) 218 S. W. 675, where the insured died of influenza contracted in camp, the court held (McCulloch, C. J. and Smith, J., dissenting) the Benham Case controlling, the policy in the later case containing language almost identical with that in the earlier.

In Myli v. American Central Life Ins. Co. of Des Moines, Iowa, (N. D.) I72 N. W. 63I (I9I9), a similar ruling had been made by the Supreme Court of North Dakota. Though the court seemed ready to decide that way on the wording of the clause under consideration-the policy.here, as in the last two Arkansas cases, contained the word "engaged"-other provisions in the policy were also relied upon to sustain the conclusion. There were provisions for payment of $\$ 4000$ in the event of the death of the insured $* * *$ while this policy is in full force, by bodily injury effected exclusively by external accidental means, not including $* * *$ nor resulting from military or naval service in time of war," etc, and for payment of benefits in case of disability, with an exception of certain injuries for which benefits were not to be paid as follows: "Excluding *** injuries resulting from military or naval service in time of war." It was argued that since these provisions clearly made mere status no 
ground for limited liability, it could not have been so intended in the clause on which the case turned, and to hold otherwise would lead to the obviously absurd result of allowing in a possible case a recovery of $\$ 4000$ for death of insured by accident while in service where such service was not a cause, and a refusal of recovery even as to the $\$ 2000$, the face of the policy, if the insured while in service died of natural causes to which conditions of service did not contribute.

In the latest case, Reid v. American Nat. Assurance Co., (Mo. App.) $218 \mathrm{~S}$. W. 957 (Feb. 28, 1920), where the policy contained the usual provision, "*** if the insured shall die $* * *$ while engaged in naval or military service in time of war," etc., the court in reversing the lower court said: "There is nothing in this policy contract warranting the instruction that in order to escape military liability there must be a finding, not only that the deceased was engaged in military service at the time of his death, but that such death was in consequence of such service." The court cites, in addition to a few of the cases above, LaRue v. Karusas Mut. Life Irs. Co., 68 Kan. 539, and Welts v. Conrs. Mut. Life Ins. Co., 48 N. Y. 34, but netiher of these cases sheds any light on the precise question here considered.

In most, if not all, of these cases it might be reasonably urged that service conditions, particularly exposure and crowded camps with inadequate health facilities, had caused or at least contributed to the illness and death. Probably there are available somewhere data showing whether the men in service ran greater risks than did civilians. In the cases above, however, there is not manifested a disposition to inquire very particularly along these lines.

There are other insurance cases which may fairly be cited in this connection. In Graves v. Krights of Maccabces, 199 N. Y. 397 (1910), there was involved a by-law of defendant providing: "No person shall be eligible for membership in the Order who is engaged either as principal, agent or servant in the manufacture or sale of $* * *$ liquors as a beverage, and should any beneficial member of the order engage in any of the above prohibited occupations after his admission, his benefit certificate shall become null and void," etc. The insured had formed a partnership with his son to conduct a saloon business, but, though insured lived in same house, he took no part in handling the business. The insurance was held avoided, rejecting argument that there - was no aroidance unless insured actually and physically participated so as to be subject to special hazards. The court said it was defendant's privilege to determine what risks it would run and it evidently thought these were moral or physical hazards in the prohibited businesses. It was further said there was no case cited controlling the point, and the "issue may seem somewhat close." Rule of the case was applied in Rauber v. Mutual Life Ins. Co., 156 App. Div. 446 (1913). See also Sovereign Camp of Woodmen of the World v. Akins, ('Tex., 1920) 219 S. W. 492.

In the field of fire insurance there are questions sufficiently like the one under consideration to make the decisions thereof applicable. In Thuringis Ins. Co. v. Norwaysz, I04 I1l. App. 390 (I902), in an action on a fire insurance policy it appeared that in violation of a provision therein the insured had kept gasoline on the premises. It was held that there was no liability, though 
there was no showing that the presence of the gasoline either caused or contributed to the fire. "Nor is it necessary to show in order to maintain a defense upon a polfy like the one in controversy, that the fire occurred by reason of the violation in such respect of the terms of the policy. The question is whether the condition of the policy has been violated." Citing Turnbull v. Home Fire Ins. Co., I63 N. Y. 237. So also Bastian v. British American, Etc. Co., $143 \mathrm{Cal} .287$ (1904), the court saying "If it were incumbent on the insurer in each case to prove that the fire was caused by dynamite being on the premises, it would render the clause in most cases of no affect;" Kensfick-Hammond Co. v. Fire Ins. Soc., 205 Mo. 294 (1907); Boyer v. Fire Ins. Co., I24 Mich. 455 (semble).

It would seem, then, that the holdings of the courts in these cases turning on the military service clause that a causal relation between the service and death must be shown in order to warrant a denial of recovery of the full amount are out of harmony with the decisions in cases fairly analogous. If there were real occasion for construction, of course it would be proper to resolve the doubt against the company in favor of the insured. It is submitted that in these cases there has been no room for such construction, not even with the word 'engaged.' To require the insurer to show a causal connection between the service and death would be to open the door to inquiries which in many cases could not be satisfactorily answered and would impose a burden on the company which as said by the California court in the Bastian Case, supra, "would render the clause in most cases of no effect."

R. W. A. 